\title{
Reducing inequities in preventable neural tube defects: the critical and underutilized role of neurosurgical advocacy for folate fortification
}

\author{
Dagoberto Estevez-Ordonez, MD, ${ }^{1}$ Matthew C. Davis, MD, MPH, ${ }^{1}$ Betsy Hopson, MSHA, ${ }^{1,2}$ \\ Anastasia Arynchyna, MPH, ${ }^{1,2}$ Brandon G. Rocque, MD, MS, ${ }^{1,2}$ Graham Fieggen, MD, MSC, ${ }^{4}$ \\ Gail Rosseau, MD, ${ }^{5}$ Godfrey Oakley, MD, MSPM, ${ }^{3}$ and Jeffrey P. Blount, MD ${ }^{1,2}$

\begin{abstract}
'Department of Neurosurgery, University of Alabama at Birmingham, Alabama; ${ }^{2}$ Children's of Alabama, Birmingham, Alabama; ${ }^{3}$ Department of Epidemiology, Rollins School of Public Health of Emory University, Atlanta, Georgia; 'Red Cross Children's Hospital, University of Cape Town, South Africa; and ${ }^{5}$ Department of Neurosurgery, NorthShore University Health System,
\end{abstract} \\ Evanston, Illinois
}

Neural tube defects (NTDs) are one of the greatest causes of childhood mortality and disability-adjusted life years worldwide. Global prevalence at birth is approximately 18.6 per 10,000 live births, with more than 300,000 infants with NTDs born every year. Substantial strides have been made in understanding the genetics, pathophysiology, and surgical treatment of NTDs, yet the natural history remains one of high morbidity and profound impairment of quality of life. Direct and indirect costs of care are enormous, which ensures profound inequities and disparities in the burden of disease in countries of low and moderate resources. All indices of disease burden are higher for NTDs in developing countries. The great tragedy is that the majority of NTDs can be prevented with folate fortification of commercially produced food. Unequivocal evidence of the effectiveness of folate to reduce the incidence of NTDs has existed for more than 25 years. Yet, the most comprehensive surveys of effectiveness of implementation strategies show that more than 100 countries fail to fortify, and consequently only $13 \%$ of folate-preventable spina bifida is actually prevented. Neurosurgeons harbor a disproportionate, central, and fundamental role in the management of NTDs and enjoy high standing in society. No organized group in medicine can speak as authoritatively or convincingly. As a result, neurosurgeons and organized neurosurgery harbor disproportionate potential to advocate for more comprehensive folate fortification, and thereby prevent the most common and severe birth defect to impact the human nervous system. Assertive, proactive, informed advocacy for folate fortification should be a central and integral part of the neurosurgical approach to NTDs. Only by making the prevention of dysraphism a priority can we best address the inequities often observed worldwide.

https://thejns.org/doi/abs/10.3171/2018.7.FOCUS18231

KEYWORDS pediatric neurosurgery; mandatory folic acid fortification; neural tube defect; spina bifida; myelomeningocele; anencephaly; infant mortality; congenital malformations

...folic acid fortification may be the most important sciencedriven intervention in nutrition and public health in decades.

$$
\text { - I. H. Rosenberg }{ }^{41}
$$

It is estimated that there are 300,000 new live births affected by neural tube defects (NTDs) worldwide each year. In the US there are approximately 1500 children born with NTDs each year. ${ }^{58}$ The indices of Global Burden of Disease indicate that NTDs are among the greatest causes of childhood mortality and disability-adjusted life years worldwide. ${ }^{26,56}$ The true mortality is likely underrepresented, as stillbirths and pregnancy terminations are usually not included. ${ }^{5}$ Mortality in children affected by NTDs is 10-fold higher than in nonaffected children, and is highest in countries of modest resources due to limitations in specialized medical and surgical care. ${ }^{2,58}$ The economic and social costs are also staggering due to a combination of lost productivity and direct and indirect medical care

ABBREVIATIONS FAP-SB = folic acid preventable SB; LMICS = low- and middle-income countries; MMC = myelomeningocele; NTD = neural tube defect; RBC = red blood cell; $S B=$ spina bifida. 
costs. ${ }^{2}$ These costs ensure profound inequities of disease burden and pronounced disparities in care between countries of abundant versus modest resources. However, up to $92 \%$ of NTDs can be prevented with mandatory folic acid fortification..$^{37}$ As a result, it is highly likely that the strategy most likely to ameliorate inequities of disease burden in NTDs is prevention rather than surgical refinement.

The most common NTD forms are myelomeningocele (MMC) and anencephaly, which represent $90 \%$ of all NTDs. ${ }^{10}$ Open MMC is classically and widely referred to as spina bifida (SB), but the spectrum of dysraphism also encompasses other variants such as meningoceles, encephaloceles, craniorachischisis, lipomyelomeningoceles, and occult spinal defects. ${ }^{7,10,16,31,49}$ Occult defects frequently go underdetected or undetected, particularly in lowresource settings, and are therefore likely underreported in the literature. ${ }^{49}$

The term "spina bifida" was first coined in 1641 by Nicholas Tulp, while the first isolated reports of surgical repair of open NTDs were recorded in the late 19th and early 20th centuries. ${ }^{18,19,53}$ These were largely proofs of a technical capability, and widespread surgical treatment of open NTDs was not embraced until the 1970s. Prior to this, most cases of open NTDs were either not treated or highly selectively treated, with only the mildest forms being considered suitable candidates for closure and subsequent care. ${ }^{44}$ It was not until the late 20 th century that substantial strides were made in understanding the pathophysiology, epidemiology, genetics, and central role of dietary folic acid fortification as an effective means of primary prevention. ${ }^{7,15,27}$

The key to many clinical advances came from epidemiological observations. ${ }^{37}$ Many of the earliest of these arose from the United Kingdom because of the prevalence and severity of NTDs in this region. Observational epidemiology studies from the middle part of the 20th century provided the key insight that the incidence of NTDs varied with multiple family variables including social class, ethnic group, maternal age, parity (number of prior pregnancies), and geographical region. ${ }^{37}$ One of the key observations was made by Smithells, who noted that poor women had babies with NTDs at a significantly higher rate, which led to the hypothesis that dietary quality was contributory. ${ }^{21,46}$

Initial studies with multivitamin supplementation were promising and set the stage for the British Medical Research Council study that found folic acid to be central to the genesis of NTDs. In this randomized trial, high-dose $(5000 \mu \mathrm{g} /$ day) oral folic acid was compared alone and in combination with other vitamin supplements. ${ }^{34}$ Only the treatment arms in which folic acid was provided realized significant reductions in NTD incidence, with a reduction of $72 \%{ }^{37}$

A multitude of subsequent studies have confirmed these findings and provided unequivocal evidence that folate fortification reliably and predictably reduces the incidence of MMC and anencephaly. ${ }^{15,27}$ These cases are referred to as folic acid preventable SB (FAP-SB) and have been subsequently shown to represent up to $92 \%$ of all clinical NTDs. This realization led to mandated fortification of wheat and corn products in the US and 80 other countries, which resulted in pronounced reductions in rates of newborn NTDs over the ensuring decades. It has been well established for at least two decades that folic acid fortification is a safe, highly effective, and inexpensive prevention strategy for NTDs, and yet rates of fortification vary widely. A 2015 survey of the extent of worldwide effectiveness of dietary folate fortification strategies found that most countries in Europe, Africa, and Asia were not fortifying grains or rice with folate, and that consequently the estimated rate of actual prevention of FAP-SB was only $13 \% .^{2}$ The lack of prevention occurs because there is insufficient political will in many countries to either pass regulations that require mandatory folic acid fortification, or to provide sufficient oversight to ensure industry actually follows the regulations for mandatory folic acid fortification. ${ }^{2,37}$

\section{Incidence and Global Disparities}

Determining the true incidence of NTDs is difficult due to the high rate of fetal mortality and spontaneous abortions, especially for those NTDs not compatible with life. ${ }^{25}$ This is particularly challenging in low- and middleincome countries (LMICs), where prenatal ascertainment is very low. Therefore, we rely chiefly on prevalence at birth as a surrogate epidemiological measure. Globally, more than 300,000 infants with NTDs are born every year. ${ }^{36}$ Worldwide prevalence at birth is approximately 18.6 cases per 10,000 live births. ${ }^{6,30}$ There is, however, significant regional, ethnic, and global variation. In the US, for example, the average birth prevalence is 7 cases per 10,000 live births. ${ }^{55}$ However, birth prevalence is higher in Hispanics compared to White Americans, but lower in African Americans. ${ }^{55}$ In certain areas of Africa, birth prevalence of NTDs can reach 75 cases per 10,000 live births, while in areas of Latin America up to 96 cases per 10,000 live births have been reported. ${ }^{42,58}$ However, estimating birth prevalence LMICs has proven to be very challenging. In Latin America, for example, only 2 countries have documented population-based monitoring, while most rely only on sporadic hospital-based reports, contributing to the wide range in prevalence reported in the literature. ${ }^{58}$ While some differences in prevalence may be due to genetic variations and clustering, most of this disparity is attributable to substantial gaps in prevention efforts. Mortality among infants with open defects can also vary significantly, with rural areas having rates approaching $100 \%$ and developed nations as low as $10 \% .^{33,44}$ Benefits in treatment and prevention have thus disproportionately bypassed LMICs, with many of these cases representing preventable deaths and disabilities. ${ }^{5,22,56,57}$ Adding to these challenges, most epidemiological studies in LMIC settings have significant limitations, and there is a lack of continued surveillance necessary to assess the efficacy of preventive efforts.

\section{Treatment Versus Prevention}

Neurosurgical treatment of NTDs is limited to prenatal or postnatal repair of MMC, treatment of associated hydrocephalus, posterior fossa decompression of the Chiari type II malformation, encephalocele or lipomyelomenin- 
gocele repair, and cord untethering..$^{10}$ More recently, the MOMs (Management of Myelomeningocele Study) trial reported randomized evidence regarding the efficacy of prenatal repair, opening the possibility for improved outcomes and a potential reduction in the need for CSF shunting, but at the risk of an increase in prenatal complications and preterm birth. ${ }^{1}$ While improved technique and better patient selection can reduce these risks, ${ }^{3,32}$ adoption of in-utero repair has been modest within the US, and still remains unavailable to most individuals in developing countries. The exceptional cost and limited availability of intrauterine MMC closure make it unlikely to exert a significant impact on the broad public health perspective of global NTD management for the foreseeable future. Furthermore, prenatal screening and ultrasound is uncommon in many low-resource areas, with nearly all NTD cases discovered at birth. Because neurosurgical intervention is unable to restore function lost due to failure of proper neural tube closure, ${ }^{7}$ all neurosurgical treatment of open NTDs remains fundamentally palliative. Therefore, primary prevention remains our most important and effective tool.

\section{Folic Acid Supplementation}

Folate is a water-soluble vitamin that may be obtained naturally as endogenous food folate or in its synthetic form (folic acid) from supplements and fortified foods. Folate is an unstable molecule, while folic acid is stable and can be incorporated into food. The earliest evidence of primary prevention of NTDs with multivitamin supplementation was provided by Smithells et al. in the early $1980 \mathrm{~s},{ }^{21,45-48}$ while later studies isolated folic acid as the major contributor to this observation. ${ }^{4,8,20,29,35,43,52,54}$ Several clinical trials and meta-analyses have since provided conclusive evidence of NTD prevention with folic acid alone, with an estimated number needed to treat of $847.5,14,23,24,27,34 \mathrm{~A}$ more recent meta-analysis also showed that there was no effect of folic acid supplementation on cleft palate, cleft lip, congenital cardiovascular defects, miscarriages, or other birth defects. ${ }^{15}$

A daily folic acid dose of $400 \mu \mathrm{g}$ can prevent the great majority of NTDs. ${ }^{17,28}$ Berry et al. showed effectiveness with a daily dose of $400 \mu \mathrm{g}$ of folic acid in the community setting in China in both high and low prevalence regions. ${ }^{4}$ The effect of prevention policies has varied substantially around the world. In the US, policies were first implemented in 1992 with a recommendation by the US Public Health Service that all women of childbearing age should consume $400 \mu \mathrm{g}$ of folic acid daily ${ }^{40}$ In 1998 , mandatory fortification of enriched cereal grain products $(140 \mu \mathrm{g} / 100$ g) was instituted. ${ }^{9,11}$ Adoption of these policies within the US has resulted in a $28 \%$ reduction in NTD birth prevalence, from 10.7 cases per 10,000 live births in 1992 to 7 cases per 10,000 live births in 1998, preventing approximately 1326 NTDs annually. ${ }^{55}$ Fortification has also lead to a decrease in serum folate deficiency levels from $30 \%$ to $<1 \%{ }^{38}$ However, after the initial reduction these policies achieved, birth prevalence of NTDs has remained stable in the US since 1999, and there are still significant gaps and opportunities for greater impact. Currently, nearly a quarter $(21.6 \%)$ of childbearing age women in the US still have red blood cell (RBC) folate concentrations levels associated with a higher risk for NTDs. ${ }^{50}$ Only a small percentage of women (17\% among Hispanic women and $30 \%$ among White women) report consuming the recommended $\geq 400 \mu \mathrm{g}$ of folic acid per day. ${ }^{51}$ In the US, NTD prevalence among Hispanics is higher than other groups, which may be due to a combination of factors such as the reported difference in consumption of the daily recommended allowance of folic acid by women of childbearing age, as well as genetic factors. Of key importance is that the FDA did not require fortification of corn masa flour, a staple food eaten by many Hispanic Americans. There could be other factors as well; for example, the methylenetetrahydrofolate reductase $\mathrm{T}$ allele, a common genetic polymorphism in Hispanics, has been associated with relatively lower plasma folate and RBC folate concentrations. ${ }^{13}$

Globally, fortification mandates are still not universally adopted (https://fortificationdata.org/\#data). For example, although maize and corn play a significant role in diet for Latin American countries, only a few have adopted fortification mandates (Fig. 1). Wheat flour fortification mandates are more widely adopted, but there are still countries that could benefit significantly from adopting these policies (Fig. 2). Neurosurgeons should take a leading role in national and international policy as well as research aimed at promoting the implementation of folic acid fortification in all countries.

\section{Mobilizing Neurosurgeons: A Call to Action}

From the first day of life, open NTDs are the purview of neurosurgeons. Through primary closure, management of hydrocephalus, posterior fossa decompression, and tethered cord release, these patients with NTDs are more closely connected to neurosurgery than virtually any other specialty. All other morbidities are secondary to disorders in neuronal innervation of end organs. Because neurosurgeons take the primary role in management of these conditions, it is incumbent on neurosurgeons to embrace a strong leadership role in prevention efforts. With increasing interest in global neurosurgery, and recognition of the vital role for neurosurgeons in global health, neurosurgeons are perfectly positioned to take a leading role in advocating for folic acid fortification efforts.

Neurosurgery is a small field that exerts a profoundly disproportionate impact. This is in large part due to the critical importance of the human central nervous system and the unparalleled ability of neurosurgeons to favorably impact the lives of patients with neurological illness. As a result, neurosurgery holds a position of societal privilege and prominence. This provides a unique and powerful position to advocate for the prevention of a profoundly severe neurological illness. Despite decades of diligent work, surgical advances remain largely palliative and the vast majority of patients with NTDs have significant lifelong morbidity. In LMICs, mortality rates remain high and the burdens of disease are profound. Associated emotional, psychological, and financial costs remain extremely high, and suffering persists at an extraordinary level. Yet, the 


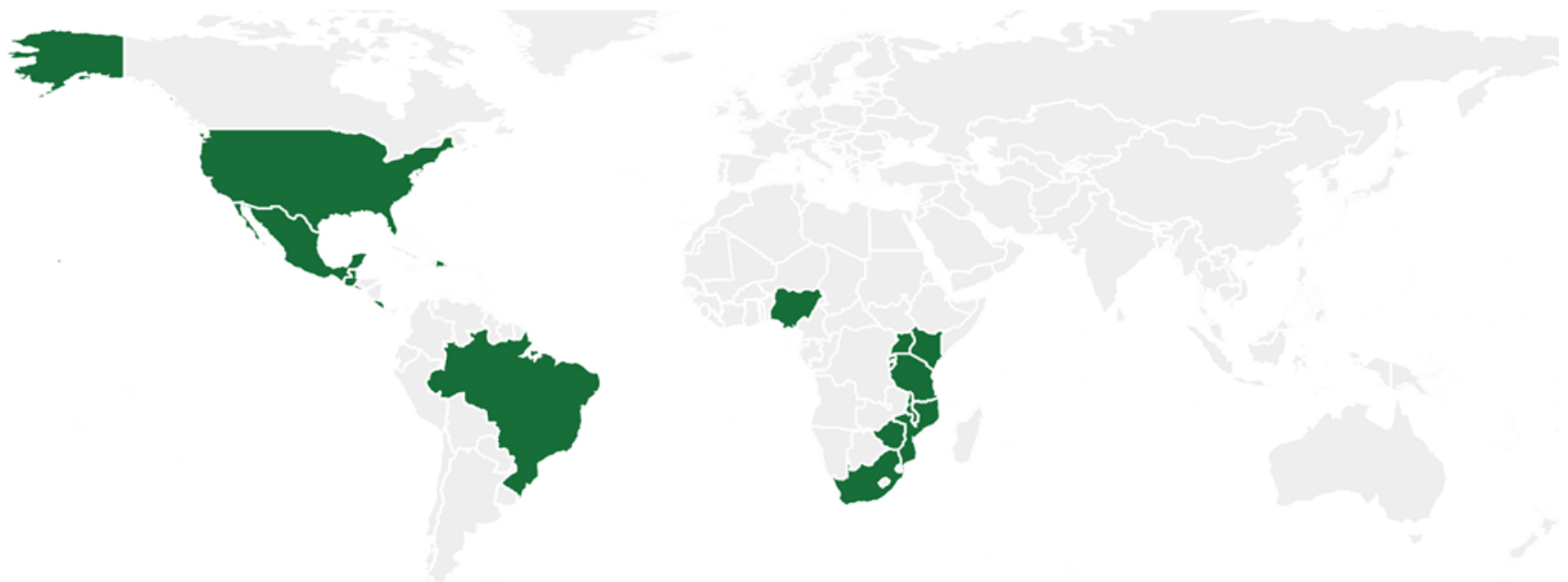

FIG. 1. Maize flour folic acid supplementation. The map displays (in green) countries that have legal documentation to either standardize ("voluntary fortification") or mandate ("mandatory fortification") food fortification with maize flour folic acid, or countries that have written standards for folic acid ("fortification standards"). Source: Global Fortification Data Exchange (https://fortificationdata. org/\#data).

fundamental disease process is largely preventable with a safe, cost effective, and simple dietary vitamin fortification. Brazil showed a 10 -fold reduction in prevalence of NTDs following fortification, while the US observed a $20 \%$ reduction in SB and a 34\% reduction in anencephaly. ${ }^{12,37,58}$ There is, to date, no significant evidence of adverse public health consequences of folic acid fortification and the cost-effectiveness ratio is a staggering 150:1.,12

\section{Implementation Steps}

Reducing inequities in neurosurgical care will require more than simply increasing capacity and advancing technical expertise. Fundamentally, neurosurgeons seek to re- duce the burden of neurological diseases across the world. Prevention of FAP-SB represents the single greatest opportunity for neurosurgeons to contribute to this goal. As the primary stewards of SB care, neurosurgeons must divorce themselves from the idea of prevention as belonging solely to the realm of public health policy. Comprehensive neurosurgical care delivery ought to incorporate prevention efforts as a central aim and inherent part of an overall strategy that improves care and eliminates inequities and disparities in the burden of dysraphic disease.

\section{Steps to Improve SB Care}

We propose the following concrete steps for both indi-

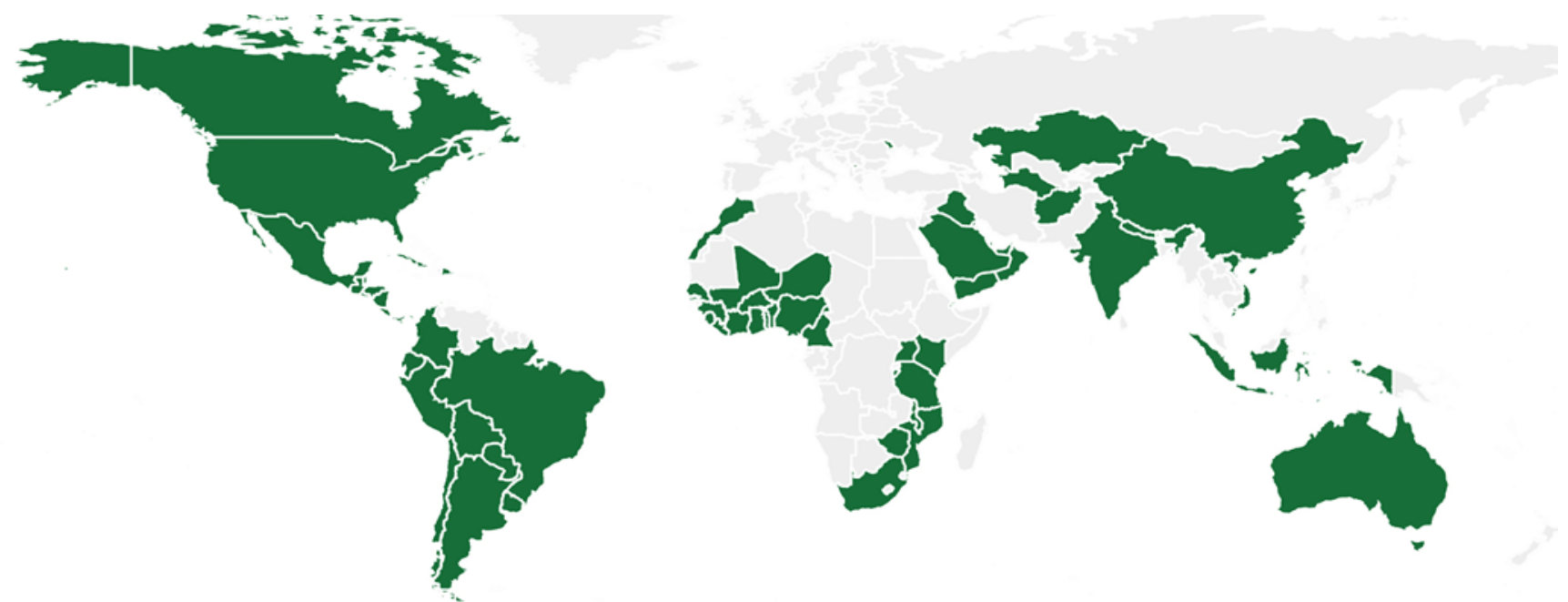

FIG. 2. Wheat flour folic acid supplementation. The map displays (in green) countries that have legal documentation to either standardize ("voluntary fortification") or mandate ("mandatory fortification") food fortification with wheat flour folic acid, or countries that have written standards for folic acid ("fortification standards"). Source: Global Fortification Data Exchange (https://fortificationdata. org/\#data). 


\section{PUSH! Global Alliance - Country Report Card: HONDURAS}

\begin{tabular}{|c|c|}
\hline $\begin{array}{l}\text { Spina Bifida - SCORE KEY } \\
\text { Excellent }=6 \text { stars } \\
\text { Good }=4-5 \text { stars } \\
\text { Improvements needed }=0-3 \text { stars }\end{array}$ & $\begin{array}{l}\text { Hydrocephalus - SCORE KEY } \\
\text { Excellent }=5 \text { stars } \\
\text { Good }=3-4 \text { stars } \\
\text { Improvements needed = 0-2 stars }\end{array}$ \\
\hline
\end{tabular}

\begin{tabular}{|c|c|c|c|c|c|c|}
\hline HONDUEAS & Folate studies & $\begin{array}{l}\text { Prevalence } \\
\text { Data }\end{array}$ & $\begin{array}{l}\text { Mortality } \\
\text { Data }\end{array}$ & Prevention & Access to Care & $\begin{array}{l}\text { Quality of } \\
\text { Life }\end{array}$ \\
\hline SPINA BIFIDA & $x$ & $\mathrm{x}$ & $x$ & & & \\
\hline HYDROCEPHALUS & N/A & $x$ & $x$ & & 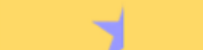 & \\
\hline RECOMMENDATIONS & $\begin{array}{l}\text { Develop surveillance capacity } \\
\text { to periodically monitor blood } \\
\text { folate status in women of } \\
\text { reproductive age }\end{array}$ & $\begin{array}{l}\text { Create surveillance systems } \\
\text { in multiple local and regional } \\
\text { hospitals, and publish } \\
\text { prevalence and mortality } \\
\text { rates for spina bifida and } \\
\text { hydrocephalus }\end{array}$ & $\begin{array}{l}\text { Create surveillance } \\
\text { systems in multiple local } \\
\text { and regional hospitals, } \\
\text { and publish prevalence } \\
\text { and mortality rates for } \\
\text { spina bifida and } \\
\text { hydrocephalus }\end{array}$ & $\begin{array}{l}\text { Spina Bifida: } \\
\text { Periodically evaluate } \\
\text { coverage and effectiveness } \\
\text { in mandatory fortification, } \\
\text { and implement required } \\
\text { remedial measures to } \\
\text { address gaps } \\
\text { Hydrocephalus: } \\
\text { Improve access to antenatal } \\
\text { care }\end{array}$ & $\begin{array}{l}\text { Improve global } \\
\text { neurosurgical education } \\
\text { and practice (e.g., } \\
\text { training, residency, } \\
\text { traveling fellowships, } \\
\text { supportive partnerships, } \\
\text { disease-specific } \\
\text { development) }\end{array}$ & $\begin{array}{l}\text { Ensure that } \\
\text { programs and } \\
\text { policies supporting } \\
\text { the rights of } \\
\text { persons with } \\
\text { disabilities are } \\
\text { implemented and } \\
\text { enforced }\end{array}$ \\
\hline
\end{tabular}

\section{Additional Information:}

No additional information is available

The report cards, developed by PUSH! Global Alliance, provide country and regional snapshots of indicators for Spina Bifida and Hydrocephalus Surveillance, Prevention and Care. For more details on the PUSH! methodology, indicators, scoring criteria, and full recommendations, please see the technical notes on next two pages or visit www.pu-sh.org.

FIG. 3. Sample Global Push report card. The report cards, developed by the PUSH! Global Alliance To Improve Nutrition and the Center for Spina Bifida Prevention/Emory University, provide country and regional snapshots of indicators for SB and hydrocephalus surveillance, prevention, and care. Reproduced with permission from the PUSH! Global Health Alliance (http://pu-sh.org/global-reportcards). For more details on the PUSH! methodology, indicators, scoring criteria, and full recommendations, visit www.pu-sh.org. ${ }^{39}$

viduals and organized neurosurgery to work together to enhance SB care.

First, neurosurgeons must serve as powerful advocates for mandatory folic acid fortification of centrally processed foods. Our professional organizations should forward evidence-based, scientifically valid position statements that support fortification and call upon Ministers of Health and elected political officials to support public health through proven prevention strategies. Neurosurgeons and neurosurgical organizations can collaborate with experts in genetics, epidemiology, and public health to call for a resurgence of commitment to programs of fortification and associated surveillance and enforcement efforts, which ensure that the vast majority of women of reproductive age consume products that are appropriately fortified with folic acid and other micronutrients recommended by the WHO. The potential power of neurosurgery in contributing to this cause is substantial. Success in a single country can prevent more disease than any neurosurgeon or neurosurgical organization can treat (palliatively) in a lifetime.

Second, neurosurgeons must form partnerships with local and international colleagues to advance basic and clinical research. This can be accomplished by provision of tissue for large-scale genomic studies of human patients with NTDs and by advocating for patient registries. Mosaic and differential tissue expression ensures the value of tissue obtained directly from regions of NTDs. Only neurosurgeons can provide the key tissue available in abundance at the time of surgical treatment.

Third, neurosurgeons must support improved registry and surveillance efforts in North America and beyond. An example of this is the National Spina Bifida Patient Registry, which is the largest currently available registry of patients with SB. This registry is sponsored and maintained by the US Centers for Disease Control and Prevention and currently has almost 9000 patients enrolled from 17 centers in North America.

Fourth, neurosurgeons should also advocate for greater prenatal screening, including ultrasound, by which open NTDs can be diagnosed.

Fifth, initiatives such as the Food Fortification Initiative, Push! Global Alliance, and the Center for Spina Bifida 
Prevention at Emory University can provide country-level information on NTD prevalence and local prevention, and can serve as partners to effect significant change (Fig. 3). ${ }^{39}$

Sixth, neurosurgeons should support the establishment of comprehensive countrywide MMC centers of excellence through a combination of advocacy, international collaboration, and funding.

Seventh, SB advocacy organizations and organized neurosurgical groups such as the World Federation of Neurological Societies, the Foundation for International Education in Neurological Surgery, and the International Society for Pediatric Neurosurgery must expand availability of multidisciplinary conferences on SB prevention and multidisciplinary management across the world. Such conferences must be interdisciplinary and include urology, orthopedics, and physical medicine and rehabilitation.

And lastly, neurosurgeons should work to establish and expand collaborations between their own institution and existing SB centers in developing countries.

\section{Conclusions}

Neurosurgeons will continue to enthusiastically debate and disseminate new surgical techniques and management strategies for patients with NTD. However, unlike the vast majority of neurosurgical diseases, in NTDs we have a condition that is eminently preventable. We have had the scientific evidence for at least 25 years, yet it is only being partially utilized and embraced. We must have science-based advocacy to impress upon public policy decision makers the critical role that folic acid fortification can play in the prevention of an otherwise devastating birth defect. Neurosurgeons must take an active leadership role in primary prevention, which is-and should be-our most powerful tool.

\section{References}

1. Adzick NS, Thom EA, Spong CY, Brock JW III, Burrows PK, Johnson MP, et al: A randomized trial of prenatal versus postnatal repair of myelomeningocele. N Engl J Med 364:993-1004, 2011

2. Arth A, Kancherla V, Pachón H, Zimmerman S, Johnson Q, Oakley GPA Jr: A 2015 global update on folic acid-preventable spina bifida and anencephaly. Birth Defects Res A Clin Mol Teratol 106:520-529, 2016

3. Bennett KA, Carroll MA, Shannon CN, Braun SA, Dabrowiak ME, Crum AK, et al: Reducing perinatal complications and preterm delivery for patients undergoing in utero closure of fetal myelomeningocele: further modifications to the multidisciplinary surgical technique. J Neurosurg Pediatr 14:108-114, 2014

4. Berry RJ, Li Z, Erickson JD, Li S, Moore CA, Wang H, et al: Prevention of neural-tube defects with folic acid in China. $\mathbf{N}$ Engl J Med 341:1485-1490, 1999

5. Blencowe H, Cousens S, Modell B, Lawn J: Folic acid to reduce neonatal mortality from neural tube disorders. Int J Epidemiol 39 (Suppl 1):i110-i121, 2010

6. Blencowe H, Kancherla V, Moorthie S, Darlison MW, Modell B: Estimates of global and regional prevalence of neural tube defects for 2015: a systematic analysis. Ann N Y Acad Sci 1414:31-46, 2018

7. Botto LD, Moore CA, Khoury MJ, Erickson JD: Neural-tube defects. N Engl J Med 341:1509-1519, 1999

8. Bower C, Stanley FJ: Dietary folate as a risk factor for neural-tube defects: evidence from a case-control study in Western Australia. Med J Aust 150:613-619, 1989

9. Centers for Disease Control and Prevention (CDC): Spina bifida and anencephaly before and after folic acid mandateUnited States, 1995-1996 and 1999-2000. MMWR Morb Mortal Wkly Rep 53:362-365, 2004

10. Copp AJ, Stanier P, Greene ND: Neural tube defects: recent advances, unsolved questions, and controversies. Lancet Neurol 12:799-810, 2013

11. Cordero A, Mulinare J, Berry R, Boyle C, Dietz W, Johnston R Jr, et al: CDC grand rounds: additional opportunities to prevent neural tube defects with folic acid fortification. MMWR Morb Mortal Wkly Rep 59:980-984, 2010

12. Crider KS, Bailey LB, Berry RJ: Folic acid food fortification-its history, effect, concerns, and future directions. Nutrients 3:370-384, 2011

13. Crider KS, Zhu JH, Hao L, Yang QH, Yang TP, Gindler J, et al: MTHFR 677C->T genotype is associated with folate and homocysteine concentrations in a large, population-based, double-blind trial of folic acid supplementation. Am J Clin Nutr 93:1365-1372, 2011

14. Czeizel AE, Dudás I, Métneki J: Pregnancy outcomes in a randomised controlled trial of periconceptional multivitamin supplementation. Final report. Arch Gynecol Obstet 255:131-139, 1994

15. De-Regil LM, Peña-Rosas JP, Fernández-Gaxiola AC, Rayco-Solon P: Effects and safety of periconceptional oral folate supplementation for preventing birth defects. Cochrane Database Syst Rev (12):CD007950, 2015

16. Detrait ER, George TM, Etchevers HC, Gilbert JR, Vekemans M, Speer MC: Human neural tube defects: developmental biology, epidemiology, and genetics. Neurotoxicol Teratol 27:515-524, 2005

17. Duffy ME, Hoey L, Hughes CF, Strain JJ, Rankin A, Souverein OW, et al: Biomarker responses to folic acid intervention in healthy adults: a meta-analysis of randomized controlled trials. Am J Clin Nutr 99:96-106, 2014

18. Forestus P: De capitis et cerebre morbis ac symptomatic, in: Observationum et curationum medicinalium, libri III. Leiden: Officina Platiniana, 1587

19. Fraser J: Spina bifida. Edinburgh Med J 36:284, 1929

20. Friel JK, Frecker M, Fraser FC: Nutritional patterns of mothers of children with neural tube defects in Newfoundland. Am J Med Genet 55:195-199, 1995

21. Hibbard ED, Smithells R: Folio acid metabolism and human embryopathy. Lancet 1:1254, 1965

22. Higashi H, Barendregt JJ, Kassebaum NJ, Weiser TG, Bickler SW, Vos T: The burden of selected congenital anomalies amenable to surgery in low and middle-income regions: cleft lip and palate, congenital heart anomalies and neural tube defects. Arch Dis Child 100:233-238, 2015

23. Kirke PN, Daly LE, Elwood JH: A randomised trial of low dose folic acid to prevent neural tube defects. Arch Dis Child 67:1442-1446, 1992

24. Laurence KM, James N, Miller MH, Tennant GB, Campbell $\mathrm{H}$ : Double-blind randomised controlled trial of folate treatment before conception to prevent recurrence of neural-tube defects. Br Med J (Clin Res Ed) 282:1509-1511, 1981

25. Little J: Fetal loss, in Elwood J, Little J, Elwood H (eds): Epidemiology and Control of Neural Tube Defects. Oxford: Oxford University Press, 1992

26. Liu L, Johnson HL, Cousens S, Perin J, Scott S, Lawn JE, et al: Global, regional, and national causes of child mortality: an updated systematic analysis for 2010 with time trends since 2000. Lancet 379:2151-2161, 2012

27. Lumley J, Watson L, Watson M, Bower C: Periconceptional supplementation with folate and/or multivitamins for preventing neural tube defects. Cochrane Database Syst Rev (3):CD001056, 2001 
28. Marchetta CM, Devine OJ, Crider KS, Tsang BL, Cordero AM, Qi YP, et al: Assessing the association between natural food folate intake and blood folate concentrations: a systematic review and Bayesian meta-analysis of trials and observational studies. Nutrients 7:2663-2686, 2015

29. Milunsky A, Jick H, Jick SS, Bruell CL, MacLaughlin DS, Rothman KJ, et al: Multivitamin/folic acid supplementation in early pregnancy reduces the prevalence of neural tube defects. JAMA 262:2847-2852, 1989

30. Mitchell LE: Epidemiology of neural tube defects. Am J Med Genet C Semin Med Genet 135:88-94, 2005

31. Mitchell LE, Adzick NS, Melchionne J, Pasquariello PS, Sutton LN, Whitehead AS: Spina bifida. Lancet 364:1885-1895, 2004

32. Moldenhauer JS, Adzick NS: Fetal surgery for myelomeningocele: after the Management of Myelomeningocele Study (MOMS). Semin Fetal Neonatal Med 22:360-366, 2017

33. Moore CA, Li S, Li Z, Hong SX, Gu HQ, Berry RJ, et al: Elevated rates of severe neural tube defects in a high-prevalence area in northern China. Am J Med Genet 73:113-118, 1997

34. MRC Vitamin Study Research Group: Prevention of neural tube defects: results of the Medical Research Council Vitamin Study. Lancet 338:131-137, 1991

35. Mulinare J, Cordero JF, Erickson JD, Berry RJ: Periconceptional use of multivitamins and the occurrence of neural tube defects. JAMA 260:3141-3145, 1988

36. Murray CJ, Lopez AD: The Global Burden of Disease: A Comprehensive Assessment of Mortality and Disability from Diseases, Injuries, and Risk Factors in 1990 and Projected to 2020. Cambridge, MA: Harvard School of Public Health, 1996, Vol 1

37. Oakley GP Jr: The scientific basis for eliminating folic acidpreventable spina bifida: a modern miracle from epidemiology. Ann Epidemiol 19:226-230, 2009

38. Pfeiffer CM, Hughes JP, Lacher DA, Bailey RL, Berry RJ, Zhang M, et al: Estimation of trends in serum and RBC folate in the U.S. population from pre- to postfortification using assay-adjusted data from the NHANES 1988-2010. J Nutr 142:886-893, 2012

39. Push! Global Alliance: Global report card for spina bifida and hydrocephlaus prevention and care. PU-SH.org (http://www. pu-sh.org/global-report-cards) [Accessed August 14, 2018]

40. Recommendations for the use of folic acid to reduce the number of cases of spina bifida and other neural tube defects. MMWR Recomm Rep 41 (RR-14):1-7, 1992

41. Rosenberg IH: Science-based micronutrient fortification: which nutrients, how much, and how to know? Am J Clin Nutr 82:279-280, 2005

42. Rosenthal J, Casas J, Taren D, Alverson CJ, Flores A, Frias J: Neural tube defects in Latin America and the impact of fortification: a literature review. Public Health Nutr 17:537-550, 2014

43. Shaw GM, Schaffer D, Velie EM, Morland K, Harris JA: Periconceptional vitamin use, dietary folate, and the occurrence of neural tube defects. Epidemiology 6:219-226, 1995

44. Shurtleff DB, Luthy DA, Nyberg DA, Benedetti TJ, Mack LA: Meningomyelocele: management in utero and post natum. Ciba Found Symp 181:270-286, 1994

45. Smithells RW, Nevin NC, Seller MJ, Sheppard S, Harris R, Read AP, et al: Further experience of vitamin supplementation for prevention of neural tube defect recurrences. Lancet 1:1027-1031, 1983

46. Smithells RW, Sheppard S, Schorah CJ: Vitamin deficiencies and neural tube defects. Arch Dis Child 51:944-950, 1976

47. Smithells RW, Sheppard S, Schorah CJ, Seller MJ, Nevin NC, Harris R, et al: Apparent prevention of neural tube defects by periconceptional vitamin supplementation. Arch Dis Child 56:911-918, 1981
48. Smithells RW, Sheppard S, Schorah CJ, Seller MJ, Nevin NC, Harris R, et al: Possible prevention of neural-tube defects by periconceptional vitamin supplementation. Lancet 1:339340, 1980

49. Stevenson RE, Hall JG: Human Malformations and Related Anomalies. Oxford: Oxford University Press, 2006

50. Tinker S, Hamner H, Crider K: Red blood cell folate concentrations among non-pregnant United States women of childbearing age, National Health and Nutrition Examination Survey, 2007-2010. Presented at the 47th Annual SER Meeting, Seattle, 2014 (Abstract) (https://epiresearch.org/ wp-content/uploads/2014/08/abstract-book-printed.pdf) [Accessed August 14, 2018]

51. Tinker SC, Cogswell ME, Devine O, Berry RJ: Folic acid intake among U.S. women aged 15-44 years, National Health and Nutrition Examination Survey, 2003-2006. Am J Prev Med 38:534-542, 2010

52. Vergel RG, Sanchez LR, Heredero BL, Rodriguez PL, Martinez AJ: Primary prevention of neural tube defects with folic acid supplementation: Cuban experience. Prenat Diagn 10:149-152, 1990

53. Von Recklinghausen F: Untersuchungen über die Spina bifida. Virchows Arch Pathol Anat Physiol Klin Med 105:373-455, 1886

54. Werler MM, Shapiro S, Mitchell AA: Periconceptional folic acid exposure and risk of occurrent neural tube defects. JAMA 269:1257-1261, 1993

55. Williams J, Mai CT, Mulinare J, Isenburg J, Flood TJ, Ethen M, et al: Updated estimates of neural tube defects prevented by mandatory folic acid fortification-United States, 19952011. MMWR Morb Mortal Wkly Rep 64:1-5, 2015

56. World Health Organization: Mortality and burden of disease estimates for WHO member states, in: WHO Health Statistics and Information Systems. Geneva: World Health Organization, 2018

57. Wu VK, Poenaru D, Poley MJ: Burden of surgical congenital anomalies in Kenya: a population-based study. J Trop Pediatr 59:195-202, 2013

58. Zaganjor I, Sekkarie A, Tsang BL, Williams J, Razzaghi H, Mulinare J, et al: Describing the prevalence of neural tube defects worldwide: a systematic literature review. PLoS One 11:e0151586, 2016

\section{Disclosures}

The authors report no conflict of interest concerning the materials or methods used in this study or the findings specified in this paper.

\section{Author Contributions}

Conception and design: Blount, Estevez-Ordonez, Davis. Acquisition of data: Davis, Oakley. Analysis and interpretation of data: Blount. Drafting the article: Blount, Estevez-Ordonez, Davis. Critically revising the article: all authors. Reviewed submitted version of manuscript: all authors. Approved the final version of the manuscript on behalf of all authors: Blount. Statistical analysis: Davis. Administrative/technical/material support: Blount, Estevez-Ordonez, Davis, Hopson, Arynchyna, Rocque, Fieggen, Oakley. Study supervision: Blount, Davis, Oakley.

\section{Correspondence}

Jeffrey P. Blount: University of Alabama at Birmingham, AL. jeffrey.blount@childrensal.org. 